\title{
A detailed morphological, phylogenetic and ecophysiological analysis of four benthic Anabaena (Nostocales, Cyanobacteria) strains confirms deep hetero- geneity within the genus
}

\author{
Andreja Kust ${ }^{1,2}$, Eliška KozlíkovÁ-ZAPOMĚLovÁ ${ }^{1,2}$, Jan MAREŠ ${ }^{1,2,3}$, Klára ŘEHÁKovÁ ${ }^{1,3}$
}

\author{
${ }^{1}$ Biology Centre of CAS, v.v.i., Institute of Hydrobiology, Na Sádkách 7, CZ-37005 České Budějovice, Czech \\ Republic; Corresponding author e-mail: andreja.kust@gmail.com, tel: +420 387775884 \\ ${ }^{2}$ University of South Bohemia, Faculty of Science, Branišovská 1760, CZ-37005 České Budějovice, Czech \\ Republic; \\ ${ }^{3}$ Institute of Botany CAS, v.v.i., Centre for Phycology, Dukelská 135, CZ-37982 Třeboň, Czech Republic
}

\begin{abstract}
Four benthic Anabaena strains isolated from different localities in the Czech Republic were examined from the morphological, phylogenetic, and physiological points of view. The results of combined analysis showed distinct morphological dissimilarity between the studied strains, which were further found to belong to different phylogenetic groups based on the 16S rRNA gene phylogeny. To assess the temperature and light (irradiance) optima of the strains, we exposed them to various combinations of these two parameters. The experiment revealed unexpectedly high temperature and light optima for some of the strains, while others showed optima that were similar to those of previously studied planktic species of related heterocytous genera. Our study is the first of its kind to be applied to benthic Anabaena strains. Our results indicate that the benthic Anabaena genus is much more complex than previously thought and provide novel insights into the biology and ecology of benthic Anabaena species. With the collection of more data, we expect the genus Anabaena will be split into several new monophyletic taxa, each covering distinct morpho- and ecotypes.
\end{abstract}

Key words: Anabaena, crossed gradients, ecology, growth optima, morphology, phylogeny, polyphyly

\section{INTRODUCTION}

Cyanobacteria are photosynthetic prokaryotes that are considered to be among the first organisms of the early Earth (BRock 1973; Schopf 1996). They are observed worldwide, in all kinds of environments (OREN 2000; Stal 2000; Castenholz 2001). In aquatic habitats, they represent one of the major groups of organisms in both planktic and benthic communities, and are capable of inhabiting wide temperature and irradiance ranges (CASTENHOlz 1969, 1973; WARD \& Castenholz 2000). One explanation of their broad distribution is the small amount of energy they require to maintain cell function and structure (VAN LIERE \& Mur 1979; Gons 1997).

Methodological improvements and new approaches applied in cyanobacterial studies have recently revealed many new taxa. Numerous traditional genera have been subdivided, usually on the basis of results of molecular analyses (KOMÁREK et al. 2014). After the introduction of new characterization methods based on a polyphasic approach (JOHANSEN \& CASAMATTA 2005; KomÁreK 2010; Osorio-SAntos et al. 2014), the traditional genus Anabaena established by Bory in 1822 (GEITLER 1932) has recently been divided (KoMÁreK \& ZAPOMĚLOVÁ 2007, 2008; WACKLIN et al. 2009; ZAPOMĚLOVÁ et al. 2009, 2012). A large group of planktic taxa with aerotopes (gas vesicles) was reclassified into the new genera Dolichospermum, Sphaerospermopsis, and Chrysosporum, primarily based on the results of 16S rRNA sequencing (ITEMAN et al. 2002; GUGGER et al. 2002; RAJANIEMI et al. 2005a,b; HofFmann et al. 2005; Willame et al. 2006). Several morphospecies, characterized by the possession of a subsymmetrical filament structure and a special type of large akinete, and forming metaphytic mats in tropical regions, have been included in the newly described genus Macrospermum (KOMÁREK 2008). After these revisions, the generic name Anabaena was preserved to include the remaining species without gas vesicles (benthic, periphytic, soil), and the 
genus is now considered to be more or less consistent. However, up until now, only a few studies have dealt with non-planktic Anabaena, whose classification is based solely on morphology (KOMÁREK 2005, 2008; SKÁCElOVÁ \& ZAPOMĚlovÁ 2010; MAREŠ 2010) or on phylogeny (HALINEN et al. 2008). The main weak point with this approach is the inadequate morphological characterization of the majority of non-planktic Anabaena strains for which 16S rRNA gene sequences are available. Thus, we have hardly any idea how big the molecular diversity of this cyanobacterial group is and how the morphological diversity of this group observed in nature is related to their evolutionary diversity. Considering this gap in current knowledge, a detailed investigation of benthic Anabaena spp. combining morphological and phylogenetic approaches is highly desirable.

Anabaena species are a common component of many types of benthic, periphytic and metaphytic mats worldwide (KOMÁREK 2013), including newly emerging habitats. Therefore, understanding their ecological demands is of exceptional importance. Knowledge about the growth preferences of benthic cyanobacteria in shallow waters is particularly interesting since their living conditions can change dramatically, even during a single day. Unlike planktic cyanobacteria, they face daily extreme fluctuations in environmental factors such as temperature, salinity, and grazing pressure (STAL 2000). The ability to live across a wide range of temperatures is a corollary of their autecological features, i.e., metabolic rate, cell composition, and population differences in growth and temperature optima (DE Nicola 1996). Several studies, such as those of StulP \& STAM (1985) and ZAPOMĚLOVÁ et al. (2008b), have dealt systematically with the growth demands of nostocacean cyanobacteria, but up to now there have been

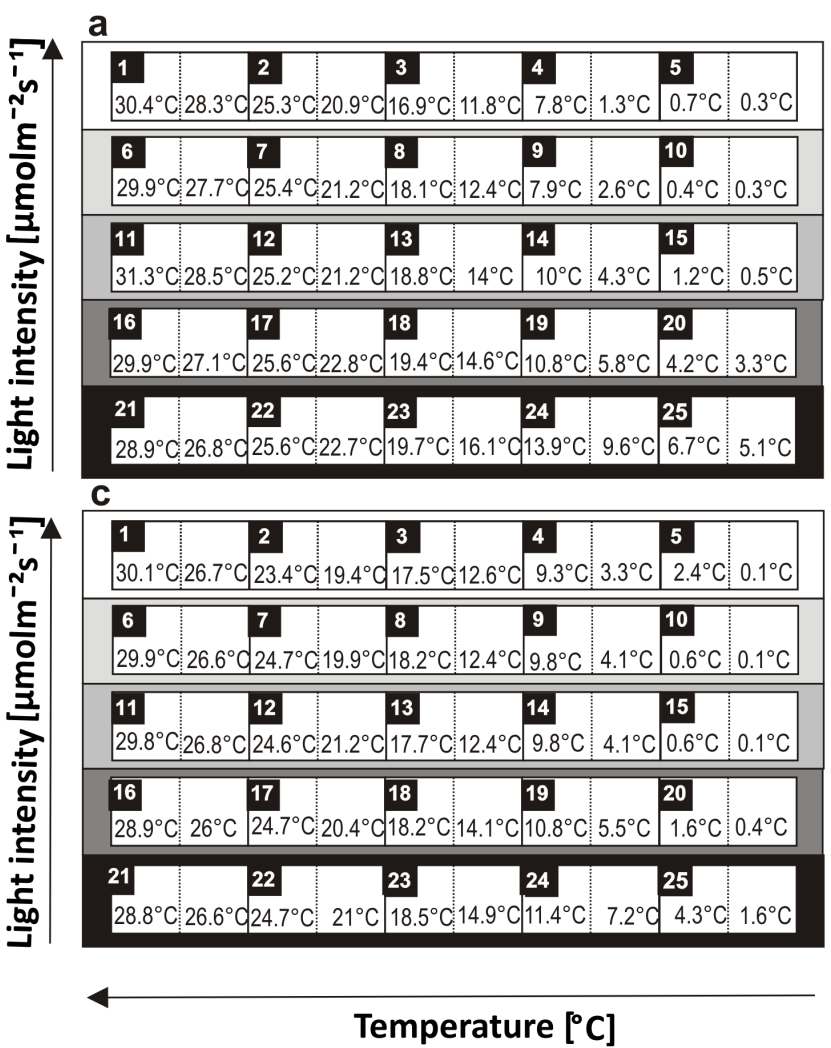

b

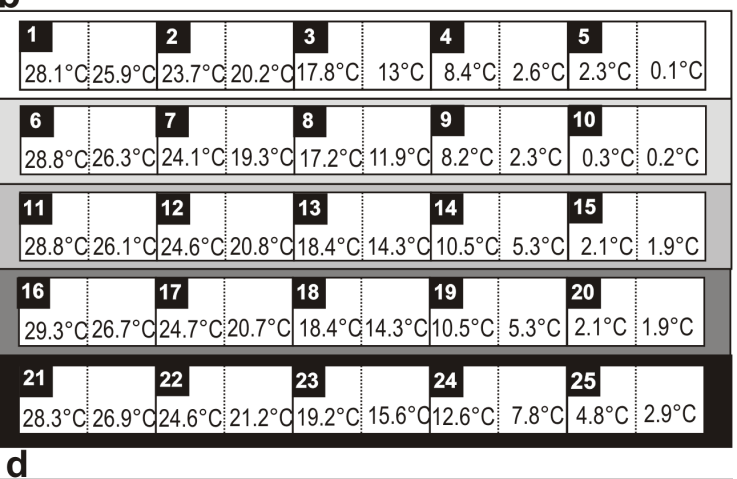

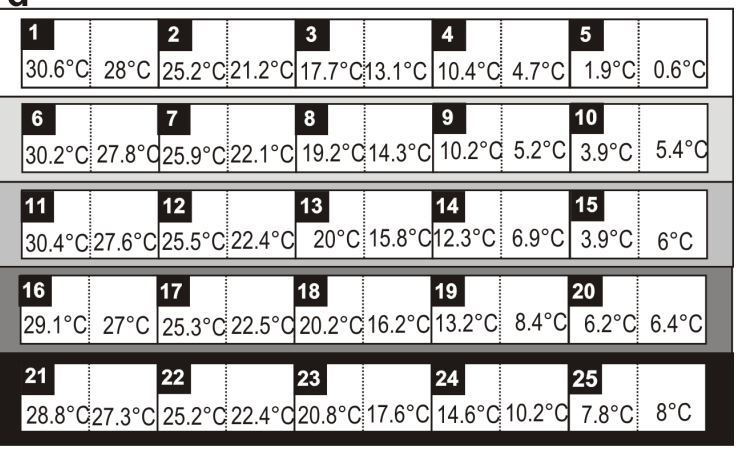

Temperature $\left[{ }^{\circ} \mathrm{C}\right]$

Light intensity $\mu \mathrm{mol} . \mathrm{m}^{-2} \cdot \mathrm{s}^{-1} \quad$ Plates numbering: used for experiment:
(a)04VR10L1
(b)11VR10JH
(c)01DRMII10
(d) $12 \mathrm{SO} 10 \mathrm{Cl}$ 1-25

Fig. 1. Design of the crossed-gradient experiment used for the determination of the light and temperature growth optima of the studied Anabaena strains. Experimental setups for the four strains studied: (a) 04VR10L1; (b) 11VR10L1; (c) 01DRMII10; (d) 12SO10CI. Gradients of light intensity and temperature are indicated with arrows. The gradient of light intensity is also indicated by shading. 
no studies assessing the optimal growth conditions of benthic Anabaena. Growth responses to environmental factors are also important because they are fundamental for water management targeting. From this point of view, a full understanding of the ecology of benthic cyanobacteria and their environmental preferences is valuable.

The aim of this study was to examine the morphological traits of four benthic Anabaena strains and assess their phylogenetic relationships to each other and to other nostocacean cyanobacteria based on $16 \mathrm{~S}$ rRNA gene sequences. Another objective was to experimentally evaluate their temperature and light preferences to enable a prediction of their ecological niches and a comparison of these preferences with those of species belonging to related planktic taxa. It is hoped that, by comparing the outputs of these three approaches, correlations/discrepancies in morphological, phylogenetic, and ecophysiological similarities of the studied strains will be uncovered, thereby yielding a more complex picture of the little studied benthic Anabaena and providing a starting point for further research.

\section{Materials ANd Methods}

Cyanobacterial Strains. Samples used for this study were collected in 2010 from localities with a water conductivity of cca $600-6000 \mu \mathrm{S} . \mathrm{cm}^{-1}$ and a $\mathrm{pH}$ in the range 5.9-7.8 (Table 1 ), which are probably caused by the high concentration of dissolved minerals released from coal mines in the vicinity, with the exception of SO-CI, which is a natural mineral spring locality. Localities were situated in the northern part of the Czech Republic (Sokolov area). VR-JH is a small lake in a former coal mining pit near Vřesová; VR-L1 is a rainwater puddle in a mine disposal site (on a soil substrate left over after coal mining) near Vřesová; and DR-MII contains drainage water from a coal mine and a SO-CI - Císařský mineral spring in the Soos protected area near Františkovy Lázně. Single trichomes were isolated from the environmental samples using a glass capillary pipette (ZAPOMĚLOVÁ et al. 2007) and the resulting strains have been maintained in the culture collection of the Biology Centre of AS CR, Institute of Hydrobiology, in WC medium (GUILLARD \& LORENZEN 1972) at $21^{\circ} \mathrm{C}$ with a light intensity of $50 \mu \mathrm{mol} \cdot \mathrm{m}^{-2} \cdot \mathrm{s}^{-1}(16: 8 \mathrm{~L}: \mathrm{D}$ cycle). The strains were used for all analyses (examination of morphological traits, phylogenetic analysis, and growth demands) within 1 year after isolation to avoid possible changes induced by long-term cultivation, especially those that result in a loss of important features (LEHTIMÄKI et al. 2000; GUGGER et al. 2002b).

Morphological Study. The morphology of the strains was examined using an Olympus BX 51 light microscope equipped with an Olympus DP 70 digital camera. Microphotographs of at least 30 trichomes per strain were taken at a magnification of $400 \times$. Morphometric characterization of the studied Anabaena strains was done based on microphotographs using the image analysis software Olympus DP Soft. Lengths and widths of all cell types were measured. Five vegetative cells per trichome were measured in 30 trichomes, 30 heterocytes, and 30 akinetes (if present) in each strain. The positions of akinetes relative to those of heterocytes were determined. Shapes of terminal cells and the length:width ratios of vegetative cells, heterocytes, and akinetes were assessed as additional characters. The identification of strains was done according to classical morphology (KoMÁREK 2013).

Molecular and Phylogenetic Study. The biomasses of the strains were harvested in the exponential phase of growth by repeated centrifugation. Samples were washed by mixing with physiological solution $(\mathrm{NaCl}$ solution, concentration 1 g..$\left.^{-1}\right)$ to remove mucilaginous substances. The centrifuged biomass samples were stored at $-20{ }^{\circ} \mathrm{C}$ until DNA extraction. DNA was extracted using an UltraClean ${ }^{\mathrm{TM}}$ Microbial DNA Isolation Kit (MO BIO Laboratories, Inc., Carlsbad, CA). The 16S rRNA gene and the adjacent rRNA ITS region was amplified using primers 16S27F (5'-AGAGTTTGATCCTGGCTCAG-3') and 23S30R (5'-CTTCGCCTCTGTGTGCCTAGGT-3') (TATON et al. 2003). Amplification was carried out as follows: an initial denaturation step of 5 min at $94{ }^{\circ} \mathrm{C} ; 10$ cycles of $45 \mathrm{~s}$ at $94{ }^{\circ} \mathrm{C}, 45 \mathrm{~s}$ at $57^{\circ} \mathrm{C}$, and $2 \mathrm{~min}$ at $72{ }^{\circ} \mathrm{C} ; 25$ cycles of $45 \mathrm{~s}$ at $94{ }^{\circ} \mathrm{C}, 45 \mathrm{~s}$ at $54{ }^{\circ} \mathrm{C}$, and $2 \mathrm{~min}$ at $72{ }^{\circ} \mathrm{C}$; followed by a final elongation step of $7 \mathrm{~min}$ at $72{ }^{\circ} \mathrm{C}$. Primers K6 (5'-GACGGGCCGGTGTGTACA- $\left.3^{\prime}\right)$, which is

Table 1. Summary of analyzed strains, including year of isolation, isolation locality, and the parameters of the localities

\begin{tabular}{|c|c|c|c|c|c|c|}
\hline Strain code & Locality & Environment & $\begin{array}{l}\text { Conductivity } \\
\left(\mu \mathrm{S} \cdot \mathrm{m}^{-1}\right)\end{array}$ & pH & GPS coordinates & $\begin{array}{l}\text { Year of } \\
\text { isolation }\end{array}$ \\
\hline 04VR10L1 & Vřesová (VR-L1) & black crust & 1230 & 7.1 & $\begin{array}{l}50^{\circ} 15^{\prime} 51.97 " \mathrm{~N} \\
12^{\circ} 43^{\prime} 4.972^{\prime \prime} \mathrm{E}\end{array}$ & 2010 \\
\hline 11VR10JH & Vřesová (VR-JH) & pond & 590 & 7.8 & $\begin{array}{l}50^{\circ} 15^{\prime} 51.94 " \mathrm{~N} \\
12^{\circ} 43^{\prime} 4.973^{\prime \prime} \mathrm{E}\end{array}$ & 2010 \\
\hline 01DRMII10 & Sokolov area (DR-MII) & drain & 6050 & 6.7 & $\begin{array}{l}50^{\circ} 16^{\prime} 18.079^{\prime \prime} \mathrm{N} \\
12^{\circ} 45^{\prime} 23.399^{\prime \prime} \mathrm{E}\end{array}$ & 2010 \\
\hline $12 \mathrm{SO} 10 \mathrm{CI}$ & $\begin{array}{l}\text { Soos Nature Reserve - } \\
\text { Císařský spring (SO-CI) }\end{array}$ & spring & 5200 & 5.9 & $\begin{array}{l}50^{\circ} 08^{\prime} 51.903^{\prime \prime N} \\
12^{\circ} 24^{\prime} 11.871 " \mathrm{E}\end{array}$ & 2010 \\
\hline
\end{tabular}


the reverse complement of Primer 14 described by Wilmotte et al. (1993), K7 (5'-AAGGAGGTGATCCA GCCACA-3') (FleChTNER et al. 2002), and 27F (5'AGAGTTTGATCCTGGCTCAG-3') (TATON et al., 2003) were used for PCR product sequencing at the Laboratory of Genomics, Biology Centre of CAS, České Budějovice, Czech Republic. Raw data from the DNA sequencer were analyzed and assembled into final nucleotide sequences using the SeqMan 5.06 (BurLAND 1999) computer program and edited manually to remove unclear bases and the variable ITS region. The DNA sequences from four studied strains were deposited in the NCBI GenBank database under accession numbers KJ679568-571. Additional sequences for phylogenetic analyses were selected from the GenBank online database (http://www.ncbi.nlm. nih.gov). All GenBank sequences included in this study are listed in Supplementary Materials. Sequences were aligned using MAFFT v. 7 (КАтоH \& StAndLey 2013) and eventual adjustments of the resulting alignments (deletion of ambiguous sites) were carried out in BioEdit v. 7.0.9.0 (HaLl 1999). The alignment was analyzed by Bayesian Inference (BI), Maximum Likelihood (ML), and Neighbor-Joining (NJ) methods. BI trees were constructed using MrBayes 3.2.3 (RoNQUIST et al. 2012) and the best ML tree was obtained using RaxML v. 8 (STAMATAKIS 2014); both phylogenies were computed using the CIPRES supercomputing facility (MILLER et al. 2012). NJ tree calculations were conducted in Seaview 4.5.3 (Gouy et al. 2010). The GTR $+\mathrm{I}+\mathrm{G}$ evolutionary model of substitution used during the ML analysis was obtained for the best fit to the data using jModelTest-2.1.4 (GuINDON \& GASCuEl 2003; Darriba et al. 2012,). Bayesian analyses were performed using two independent runs, each with four Markov chains that were run for 1375000 generations with the default likelihood model (without weighing of bases or base changes) until the average standard deviation of split frequencies was lower than 0.01 . For $\mathrm{NJ}$ and $\mathrm{ML}$ analyses, 1000 bootstrap pseudoreplications with default parameters were performed to evaluate the relative support of branches. The topology of the final phylogenetic tree was derived from that of the BI tree. Trees were rooted using 16S rRNA gene sequences of outgroup non-heterocytous cyanobacteria Gloeobacter violaceus PCC 7421, Trichodesmium erythraeum IMS 101, Synechococcus sp.1tu21s05, and Cyanobium sp. JJ10-3. Trees were edited using FigTree v. 1.4.2 (http://tree. bio.ed.ac.uk/software/figtree).

Crossed-Gradient Experiment. Crossed gradients (KvíDEROVÁ \& LUKAVSKÝ 2001) were used to determine the growth preferences of the four Anabaena strains. The experimental table enabled us to establish different combinations of light intensity and temperature. The strains were exposed in sterile culture plates $(9 \times 12 \mathrm{~cm}, 6$ wells, $16 \mathrm{ml}$ each) to 50 different combinations (Fig. 1). The temperature gradient was set directly on the table and particular levels of light intensities were achieved by shading. Two replicates of strains were done for each combination of light and temperature. Ranges of temperature and light were modified for each strain according to the results of a pilot experiment (data not shown). The temperature ranged from 0.0 to $31.3{ }^{\circ} \mathrm{C}$, and the range of light intensity was $2-830 \mu \mathrm{mol} \cdot \mathrm{m}^{-2} \cdot \mathrm{s}^{-1}$. The duration of each experiment was about 2 weeks. The experiments were terminated when the fastest-growing culture (corresponding to the optimal experimental condition) reached the late exponential phase of growth. The late exponential phase was indicated by a slightly yellowish colour of the growing biomass. After the termination of experiments, chlorophyll $a$ 


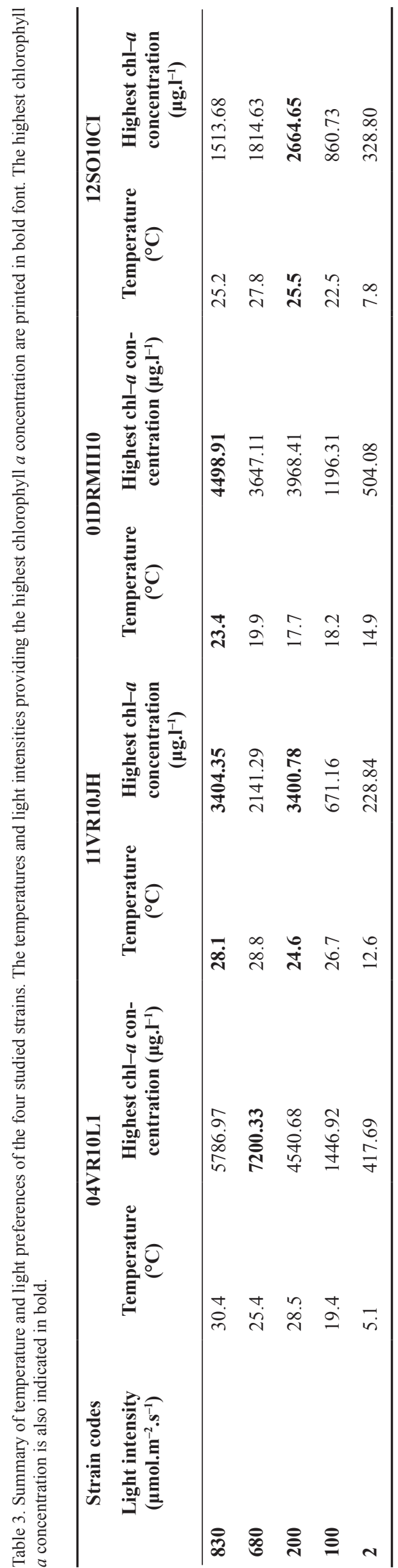

concentrations were determined spectrophotometrically after acetone extraction (LORENZEN 1967) and compared between the individual positions of the crossed gradients. The light and temperature growth preferences of the strains were obtained from a Scatter Chart using R (v.3.1.1; R Development Core Team, 2014).

\section{Results}

\section{Morphology}

Morphological characters and dimensions of the studied Anabaena strains are shown in Table 2. Important morphological features (vegetative cells, terminal cells, heterocytes and akinetes) are further visible in Figure 2. The vegetative cell dimensions and their proportions differed between the different strains, which enabled the recognition of two main morphological types. Strains 04VR10L1, 01DRMII10 and 12SO10CI represent a group with more or less isodiametric vegetative cells, while another morphotype with shorter than wide vegetative cells with a barrel-shape is represented by strain 11VR10JH. Moreover, akinetes were found adjacent to heterocytes in all strains except for 01DRMII10, in which they were situated distant from heterocytes, usually at a distance of 3-10 vegetative cells. Terminal cells in strain 04VR10L1 were pointed, unlike in the other strains where the terminal cells were rounded. The morphological comparisons demonstrated that the strains belong to different morphological groups. Two morphospecies were identified according to currently-used species-defining morphological criteria: strain $12 \mathrm{SO} 10 \mathrm{CI}$ was identified as Anabaena oscillarioides, and strain 01DRMII10 as Trichormus variabilis (syn. Anabaena variabilis). Morphological identification of these two strains was in agreement with their phylogenetic position (see below). The remaining two strains (04VR10L1 and 11VR10JH) were impossible to identify because of the insufficient number of observed akinetes, which are crucial for species determination within the Anabaena/Trichormus group (RAJANIEMI et al. 2005).

\section{Phylogenetic Relationships}

Partial 16S rRNA gene sequences (1361 bp) of the four studied Anabaena strains were compared with a representative set of sequences available from GenBank. BI, ML and NJ phylogenetic algorithms produced similar topologies; thus only the BI tree is presented here. The bootstrap supports obtained using the ML and NJ methods are given in this tree (Fig. 3). Sequences of nonplanktic Anabaena were recovered as highly polyphyletic in our phylogeny, forming at least eight separate clades. Each of the four Anabaena strains analyzed in this study appeared in one of these different clusters, which was supported by relatively high bootstrap values (Fig. 3). Strains 04VR10L1 and 11VR10JH formed two isolated lineages that were remotely related 


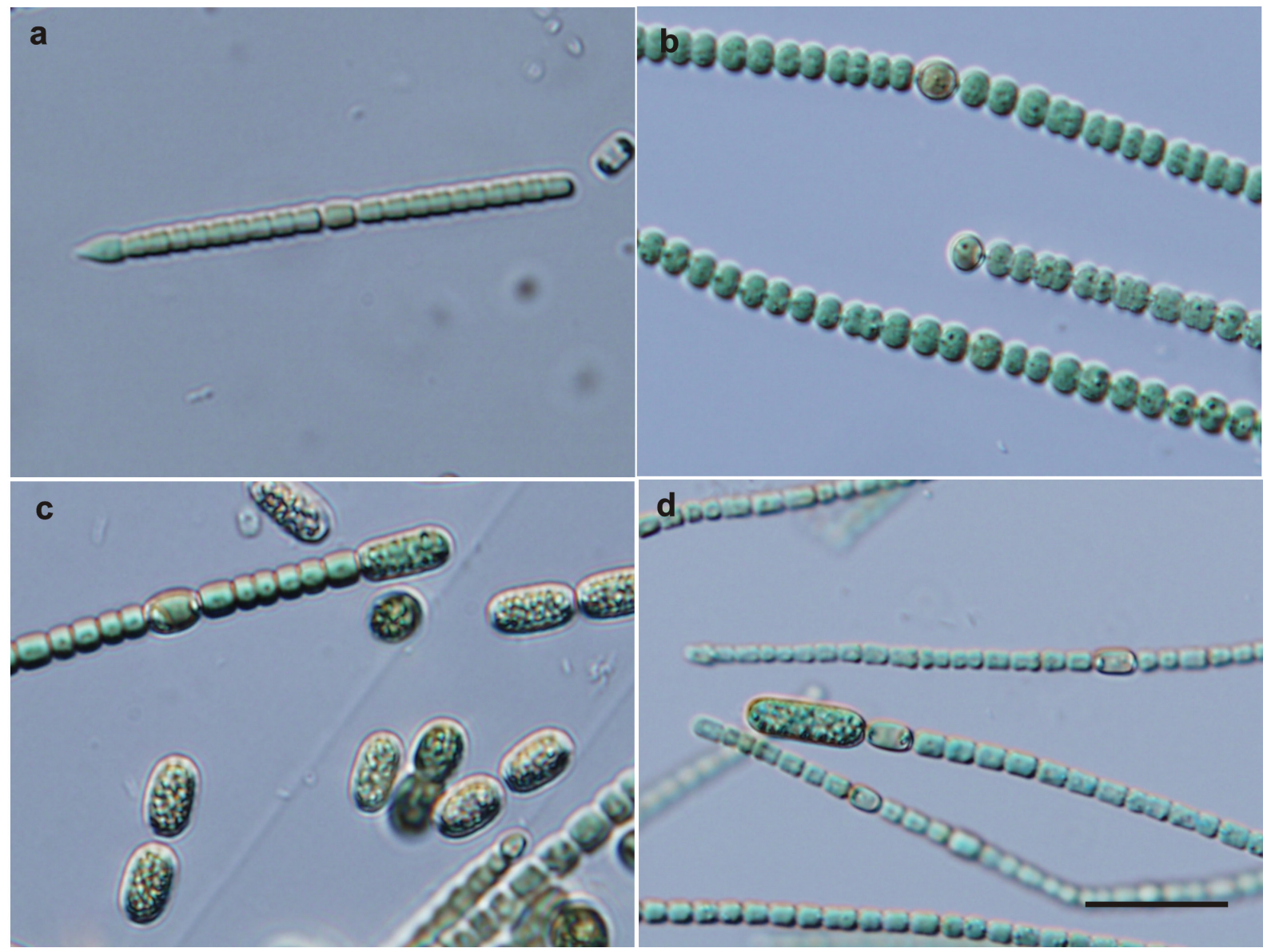

Fig. 2. Microphotographs of the four studied Anabaena strains. Strain codes: (a) 04VR10L1; (b) 11VR10JH; (c) 01DRMII10; (d) 12SO10CI. Scale bar $20 \mu \mathrm{m}$.

to two different clades of benthic Anabaena spp. Strain 12SO10CI grouped tightly in an Anabaena oscillarioides/Anabaena sp. cluster, in agreement with its morphological identification (A. oscillarioides). Similarly, strain 01DRMII10, identified as Trichormus variabilis based on its morphology, clustered together with Anabaena sp. and two Trichormus variabilis strains with high bootstrap support.

\section{Growth Preferences}

Temperature and light growth optima were taken to be those that yielded the highest chlorophyll- $a$ concentration. While the temperature and light intensity optima that produced the highest chlorophyll- $a$ concentration were evident for three of the strains, strain 11VR10JH gave ambiguous results. The highest chlorophyll $a$ concentrations for this strain occurred at $28.1{ }^{\circ} \mathrm{C}$ and $830 \mu \mathrm{mol} . \mathrm{m}^{-2} . \mathrm{s}^{-1}$, both of which are unexpectedly high. The second highest concentration, differing in only $4 \mu \mathrm{g} . \mathrm{l}^{-1}$, occurred at $24.6{ }^{\circ} \mathrm{C}$ and $200 \mu \mathrm{mol} \cdot \mathrm{m}^{-2} \cdot \mathrm{s}^{-1}$. The temperature preferences of the other strains were roughly similar, while the light preferences of strains 04VR10L1 and 01DRMII10 were remarkably high and differed from each other (Table 3, Fig. 4). The optimal light preference of strain 12SO10CI $\left(200 \mu \mathrm{mol} \mathrm{m}^{-2} \mathrm{~s}^{-1}\right)$ was lower than those of the other strains. The results showed that the chlorophyll- $a$ concentration was low in all the strains at low irradiance $\left(2 \mu \mathrm{mol} . \mathrm{m}^{-2} . \mathrm{s}^{-1}\right)$ and across the entire temperature range. At temperatures below $10-15^{\circ} \mathrm{C}$, the chlorophyll- $a$ concentration was low in all the strains irrespective of light intensity. In general, the chlorophyll- $a$ concentrations of the strains differed. Some of the strains, for example 04VR10L1, accumulated the highest chlorophyll- $a$ concentration (over $7000 \mu \mathrm{g} . \mathrm{l}^{-1}$ ) at $630 \mu \mathrm{mol} . \mathrm{m}^{-2} \cdot \mathrm{s}^{-1}$ and $25.4{ }^{\circ} \mathrm{C}$, while strain $12 \mathrm{SO} 10 \mathrm{CI}$ accumulated the lowest concentration $\left(6.78 \mu \mathrm{g} . \mathrm{l}^{-1}\right)$ at $830 \mu \mathrm{mol} . \mathrm{m}^{-2} . \mathrm{s}^{-1}$ and $4.7^{\circ} \mathrm{C}$. Average values of chlorophyll- $a$ concentration also differed between the strains (04VR10L1, $1497.29 \mu \mathrm{g} .1^{-1}$; 11VR10JH, $628.36 \mu \mathrm{g} .1^{-1}$; 01DRMII10, $1378.42 \mu \mathrm{g} .1^{-}$ '; and 12SO10CI, $\left.635.33 \mu \mathrm{g} .1^{-1}\right)$.

\section{Discussion}

The phylogenetic tree inferred from 16S rRNA gene sequences revealed clustering of the four Anabaena strains into separate, relatively little related clades that broadly correlated with their morphologies. Members 
1/100/100 Cyanobium sp. AM710342

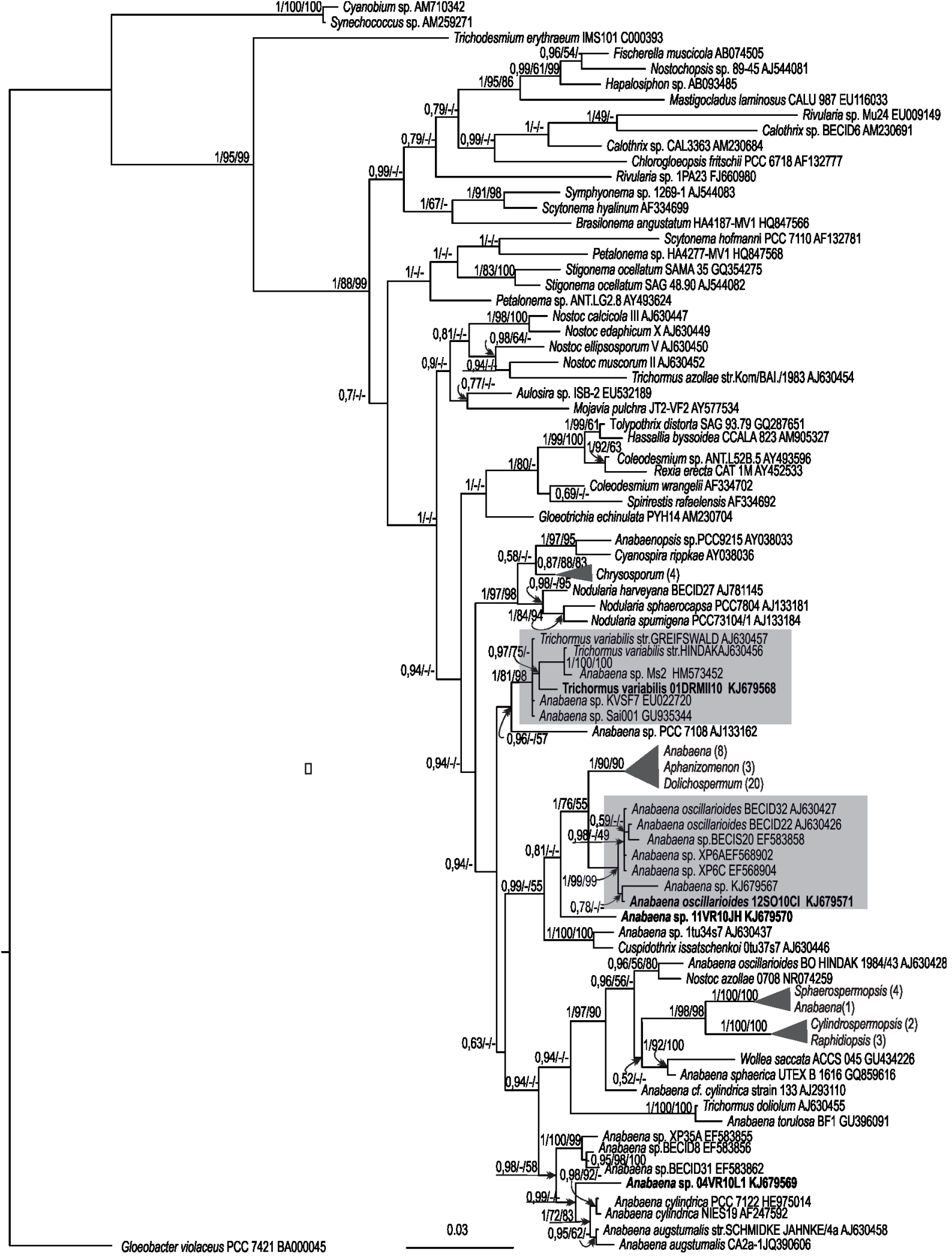

Fig. 3. Bayesian inference (BI) tree based on 16S rRNA data (1361 bp) showing the clustering of Anabaena morphospecies without gas vesicles from the Czech Republic (sequences obtained in this work are in bold, clusters containing identified strains are highlighted). Numbers near the nodes indicate branch support values over 50\% for BI, Maximum Likelihood (ML), and Neighbor-Joining (NJ) analyses in the following order: BI/ML/NJ. Sequences are labeled with taxon name, strain code, and GenBank accession number. Synechococcus sp. 1tu21s05, Cyanobium sp. JJ10-3, Gloeobacter violaceus PCC 7421, and Trichodesmium erythraeum IMS 101 are outgroup taxa. 


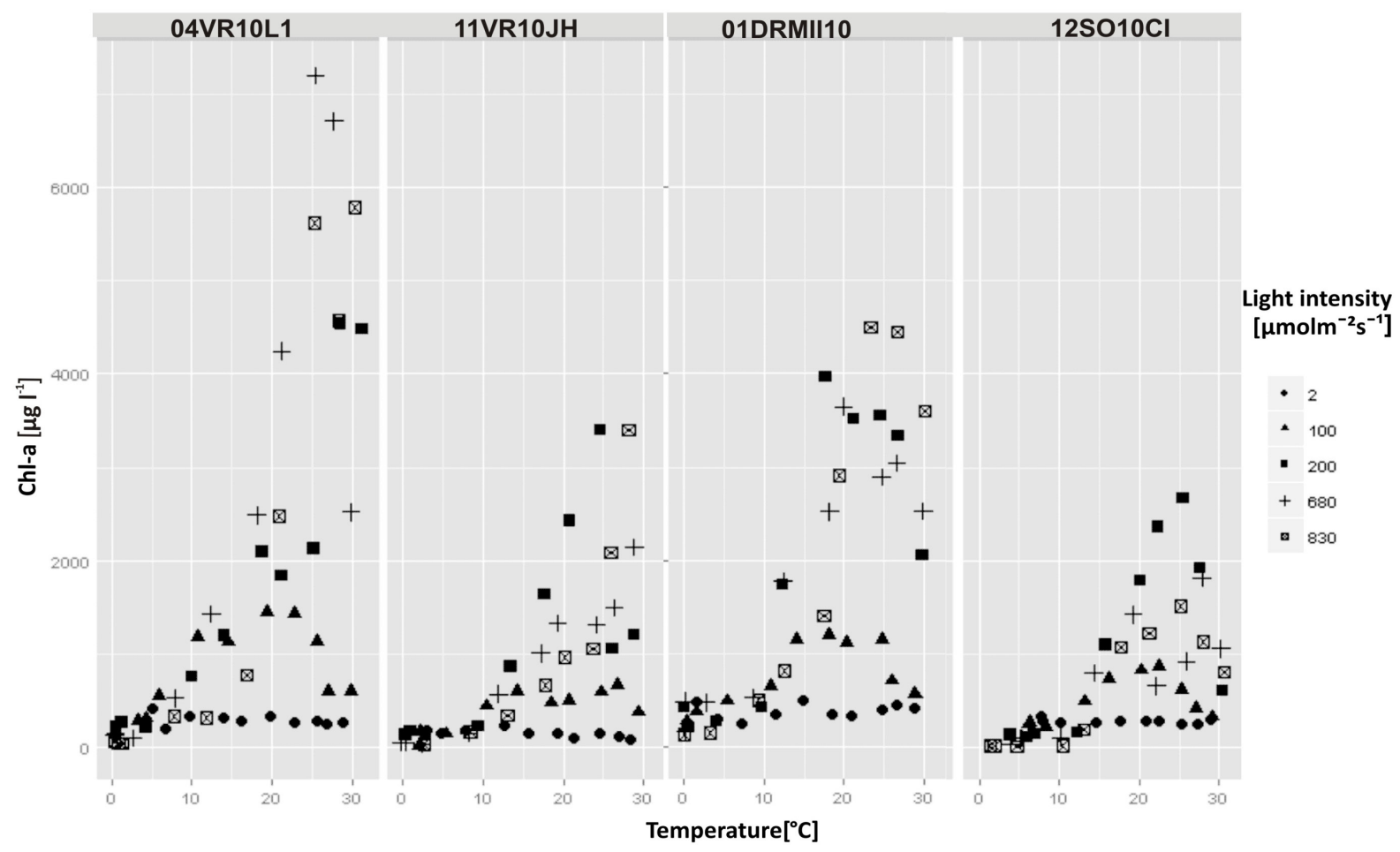

Fig. 4. Scatter Charts describing chlorophyll- $a$ concentrations $\left[\mu \mathrm{g} \cdot 1^{-1}\right]$ of the strains as a function of temperature and light. Identical inocula of each strain were exposed to various combinations of temperature and light intensity. The biomass was harvested in the exponential phase of growth corresponding to that of the fastest-growing culture, and chlorophyll- $a$ concentrations were determined.

of non-planktic Anabaena were resolved as highly polyphyletic, with sometimes a more distant relationship between themselves than with other species of other Nostocacean genera (for example, Trichormus, Dolichospermum, and Aphanizomenon). These findings are in accordance with those of HALINEN et al. (2008), who also identified several relatively unrelated phylogenetic clusters of benthic Anabaena spp. Trichormus, belonged for a long time to the genus Anabaena and only recently was separated from this genus on the basis of its apoheterocytic akinete development (RAJANIEMI et al. 2005). Some of the Anabaena strains (01DRMII10 and related Anabaena sp.) in our phylogeny formed a tight cluster together with members of the genus Trichormus (Fig. 3), namely, with a couple of strains identified as its type species T. variabilis (former Anabaena variabilis). Based on the high bootstrap support, and the fact that the morphology of 01DRMII10 matched that of T. variabilis, an affiliation of these strains with true Trichormus should be considered. However, there is no clear morphological description available for the other Anabena sp. in this cluster, and further polyphasic examinations will be required before any decision can be made. Strains of other species assigned to Trichormus (T. azollae and T. doliolum) clustered in completely different positions in the tree, once again emphasizing the polyphyly of the genus (RAJANIEMI et al. 2005; HrouzeK et al. 2013), which is in urgent need of a comprehensive taxonomic revision.
Strain 12SO10CI was identified as Anabaena oscillarioides based on its morphology and source habitat. This conclusion was further supported by its position in a cluster of several strains designated as A. oscillariorides and Anabaena sp. Because A. oscillarioides is the type species of Anabaena, this lineage may be a candidate for the definition of "true" Anabaena. Nevertheless, as demonstrated earlier (RAJANIEMI et al. 2005; Kozhevnikov \& Kozhevnikova 2011), putative $A$. oscillarioides can be found at least in one more, relatively distant lineage (see also Fig. 3, strain BO HINDAK 1984/43). There are currently not as many sequences available for this genus as there are for planktic taxa, and, moreover, the strains are usually poorly defined. One of the reasons for this lies in the morphological plasticity of Anabaena and their frequent lack of morphological features that are critical for identification during the different parts of its life cycle or when it is grown under culture conditions. This was also the case for two strains in our study that could be identified solely as Anabaena sp. because they lacked akinetes.

The results of this study further support the distinction of planktic Dolichospermum, Sphaerospermopsis, and Chrysosporum (ZAPOMĚLOVÁ et al. 2009, 2011, 2012) from benthic Anabaena strains. On the other hand, HALinen et al. (2008) showed that some non-gas-vacuolate Anabaena spp. are intermixed with planktic Dolichospermum strains. The occurrence of aerotopes was demonstrated to be an unstable feature 
of species in some related cyanobacterial taxa, especially after long-term cultivation (КомÁREK et al. 1993; LAAMANEN et al. 2001). Thus, detailed molecular and morphological studies involving a larger set of populations are still required to test this hypothesis.

Alongside phylogeny, the morphology of the studied Anabaena strains confirmed the considerable morphological and genotypic polymorphy within benthic Anabaena. However, the morphology and phylogeny of the studied strains were generally congruent, which is in contrast to studies where the observed morphological variability is sometimes not reflected in the genetic relationships based on 16S rRNA sequences (Lyra et al., 2001; Iteman et al. 2002; GugGer \& HoffMAnN 2004; ŘehÁKová et al. 2014). On the other hand, it was difficult to find a correlation between the growth response of the studied strains to various light intensities and temperatures and their morphological or phylogenetic variability. Strain 01DRMII10 was clearly distinct from other strains based on its morphology and phylogeny, whereas it was not different from other strains with respect to its growth optima. Strain 12SO$10 \mathrm{CI}$ had growth preferences that were the most different from those of the other studied strains, while the results of strain $11 \mathrm{VR} 10 \mathrm{JH}$ were ambiguous, similar to both 01DRMII10 and 04VR10L1. In contrast to our results, MiLler \& CASTEnHOLZ (2000) showed that strains of Synechococcus isolated from Oregon hot springs that grouped into different phylogenetic lineages have different temperature growth optima. Apparently, ecophysiological niche differentiation in cyanobacteria can rapidly evolve in response to the selective pressure of the environment (Coleman et al. 2006). Hence, the correlation of growth optima with morphology or phylogenetic position can be expected only in extremely tightly related populations, which was not the case for our strains.

Since benthic or periphytic species often have to face severe fluctuations in temperature and light intensity (STAL 2000), we expected their growth optima or tolerances to be lower or higher than those of their planktic counterparts. Indeed, some of the studied strains showed remarkably high temperature and light preferences. Interestingly, strains showing preference for a higher light intensity (01DRMII10 and 04VR10L1) were isolated from localities with shallow water, with high exposure to sun irradiance. Strains preferring higher light intensities had also higher chlorophyll $a$ concentrations (an approximation of biomass), which is in agreement with the greater photosynthetic yield expected from an increased energy input. We did not observe any link between the conductivity or the water $\mathrm{pH}$ of the localities and morphology or phylogenetic clustering.

Our strains survived over the whole experimental temperature range $\left(0.0-31.3{ }^{\circ} \mathrm{C}\right)$, and at light intensities 2-830 $\mu \mathrm{mol} \cdot \mathrm{m}^{-2} \cdot \mathrm{s}^{-1}$. Most of the studied strains (04VR10L1, 11VR10JH, and 01DRMII10) showed similar light intensity optima, which were relatively close to those of previously studied planktic species of Dolichospermum (ZAPOMĚLová et al. 2008a). The Dolichospermum strains exhibited an ability to grow over a wide temperature range $\left(10-28{ }^{\circ} \mathrm{C}\right)$, but some of them did not survive extremely low or high light intensities $\left(20 \mu \mathrm{mol} . \mathrm{m}^{-2} . \mathrm{s}^{-1}, 750 \mu \mathrm{mol} . \mathrm{m}^{-2} \cdot \mathrm{s}^{-1}\right)$ (ZAPOMĚLOVÁ et al. 2008a). Although cyanobacteria generally require little energy to maintain cell function and structure (Gons 1997; VAn Liere \& Mur 1979), the low light intensities employed were apparently insufficient to provide the minimal amount of energy necessary for the growth of Dolichospermum strains studied by Zapomělová et al. (2008a). Their death at high light intensities could be explained by oxidative stress and photoinhibition (VAn Liere \& Mur 1980; HerMAN \& D'ARI 1998; MulLer 2000). In general, planktic strains seem to be adapted to a more homogenous and stable environment without the need for mechanisms to protect against abrupt changes in environmental conditions, whereas the benthic strains investigated in this study presumably possess protective mechanisms that allow them to grow over a wide range of temperatures and light intensities. Such mechanisms possibly involve increased carotenoid production to protect cells from photoinhibition (PAERL et al. 1983) or efficient cyclic electron flow (Marathe 2012). Considering that the four strains used in this study were collected from different sampling sites, their morphological differences, clustering in different phylogenetic lineages, and variable growth preferences are not very surprising. Previously, Rapala \& Sivonen (1998) referred to strain-specific differences in growth rates of various planktic Anabaena strains (recently reclassified to Dolichospermum) exposed to different temperature and light conditions. Similarly, ZAPOMĚLOVÁ et al. (2008b) described the markedly different and non-overlapping temperature and light optima of different strains in the species complex of Dolichospermum circinale / D. crassum.

Our study contributes to the current knowledge on non-gasvaculate Anabaena mostly by combining the morphological, phylogenetic and eco-physiological approaches in attempt at obtaining a congruent picture of the studied strains. Although the study itself is based solely on four strains, it summarizes and validates the methodological approaches, and provides the starting point for further studies within this intriguing group of cyanobacteria. The main weak point of previous phylogenetic studies of non-planktonic Anabaena-like cyanobacteria was the missing analysis of morphology. Furthermore, growth preferences of benthic Anabaena species have not been experimentally assessed before. Some of the strains included in the current study exhibited much higher light intensity preferences compared to their planktonic counterparts, raising further questions related to their biology and ecology. 
Our study has once again stressed the importance of combining different approaches to reach reliable conclusions about individual cyanobacterial species and populations, which in turn should result in improvements in the taxonomy of cyanobacteria and better resolution of their life history. The phylogenetic heterogeneity (polyphyly) of the studied strains indicates that benthic and periphytic Anabaena will certainly have to be divided into several genera. Further investigation is necessary to reveal the whole range of the diversity of this cyanobacterial group and to create a reliable taxonomic classification. Taken together with the results of previous studies, our results show that the growth demands of related planktic and benthic cyanobacteria differ substantially from each other. This can be explained by their different life strategies, resulting from the different properties of their habitats. Planktic species usually live in relatively stable environments, whereas benthic species inhabit environments with extremely fluctuating conditions (light intensity, temperature, water and nutrient availability, grazing pressure etc.). Moreover, benthic or periphytic mats can occur during the whole year, whereas those of planktic species of cyanobacteria predominantly occur during the warmer season. The results of this study indicate that benthic Anabaena species can tolerate wider fluctuations in temperature and light intensity than their planktic counterparts. Further investigation of the physiological and biochemical aspects of these growth preferences is desirable.

\section{ACKNOWLedgments}

We would like to thank Martina Kaňová and Marie Kupková from the Biology Centre of AS CR, Institute of Hydrobiology, for the valuable technical assistance. This research was supported by funding from the Czech Science Foundation, project no. 14-18067S, by the long-term research development project no. RVO67985939 of the Czech Academy of Sciences and by the grant of the Faculty of Science, University of Sout Bohemia. Grant no. GAJU 04-145/2013/P.

\section{REFERENCES}

BRock, T.D. (1973): Evolutionary and ecological aspects of the cyanophytes. - In: CARR, N. G. \& Whitton, B. A. (eds): The Biology of the Blue-Green Algae. - pp. 487-500. Blackwell Scientific Publications, Oxford.

Burland, T.G. (1999): DNASTAR's Lasergene Sequence Analysis Software. - Methods in Molecular Biology 132: 71-91.

Castenholz, R.W. (1969): Thermophilic blue-green algae and the thermal environment. - Bacteriology Reviews 33: 476-504.

Castenholz, R.W. (2001): General characteristics of the cyanobacteria. - In: CASTEnHolz, R. W. \& Boone, D. R. (eds): Bergey's Manual of Systematic Bacteriology:1. - pp. 474-487, 2nd ed., Springer - Verlag, New York.

Castenholz, R.W. (1973): Ecology of blue-green algae in hot springs. - In: CARR, N.G. \& WhitTon B.A. (eds):
The Biology of Blue-Green Algae. - pp. 379-414. Blackwell Scientific Publications, Oxford.

Coleman, M.; Sullivan, M.B.; Martiny, A.C.; Steglich C.; Barry, K.; Delong, E.F. \& Chisholm, S.W. (2006): Genomic Islands and the Ecology and Evolution of Prochlorococcus. - Science 311: 1768-1770.

Darriba, D.; Taboada, G.L.; Doallo, R. \& Posada, D. (2012): jModelTest 2: more models, new heuristics and parallel computing. - Nature Methods 9: 772.

DeNicola, D.M. (1996): Periphyton responses to temperature at different ecological levels. - In: STEvenson, R.J.; Bothwell, M.L. \& Lowe, R.L. (eds): Algal ecology: freshwater benthic ecosystems. Academic Press. - pp. 149-181, San Diego, California.

Flechtner, V.R.; Boyer, S.L. \& Johansen, J.R. (2002): Spirirestis rafaelensis gen. et sp. nov. (Cyanophyceae), a new cyanobacterial genus from arid soils. Nova Hedwigia 74: 1-24.

Geitler, L. (1932): Cyanophyceae. - In: Rabenhorst, L. (eds): Kryptogamen-Flora von Deutschland, Österreich und der Schweiz. - pp. 673-1056, Akademische Verlagsgesellschaft, Leipzig, Germany.

Gons, H.J. (1977): On the light-limited growth of Scenedesmus protuberans Fritsch [PhD Thesis]. - 120 pp., University of Amsterdam, Amsterdam.

Gouy, M.; Guindon, S. \& Gascuel, O. (2010): SeaView version $4:$ a multiplatform graphical user interface for sequence alignment and phylogenetic tree building. - Molecular Biology and Evolution 27: 221224.

Gugger, M. F. \& Hoffman, L. (2004): Polyphyly of true branching cyanobacteria (Stigonematales). - International Journal of Systematic and Evolutionary Microbiology 54: 349-357.

Gugger, M.; Lyra, C.; Henriksen, P.; Couté, A.; Humbert, J.F. \& Sivonen, K. (2002): Phylogenetic comparison of the cyanobacterial genera Anabaena and Aphanizomenon. - International Journal of Systematic and Evolutionary Microbiology 52: 1-14.

Guillard, R.R.L.; Lorenzen, C.J. (1972): Yellow-green algae with chlorophyllide c. - Journal of Phycology 8: $10-14$.

Guindon, S. \& Gascuel, O. (2003). A simple, fast and accurate method to estimate large phylogenies by maximum-likelihood". - Systematic Biology 52: 696-704.

Halinen, K.; Fewer, D.P.; Sivonen, L.M.; Lyra, C.; EroNen, E. \& Sivonen, K. (2008): Genetic diversity in strains of the genus Anabaena isolated from planktonic and benthic habitats of the Gulf of Finland (Baltic Sea). - FEMS Microbiology Ecology 64: 199-208.

HALl, T.A. (1999): BioEdit: a user-friendly biological sequence alignment editor and analysis program for Windows 95/98/NT. - Nucleic Acids Symposium Series 41: 95-98.

Herman, C. \& D' Ari, R. (1998): Proteolysisand Chaperones: The Destruction/Reconstruction Dilemma. Current Opinion in Microbiology 1: 204-09.

Hoffman, L.; KomÁRek, J. \& Kaštovský, J. (2005): System of cyanoprokaryotes (cyanobacteria) - state in 2004. - Algological Studies 117: 95 -115.

Hrouzer, P.; Lukešová, A.; Mareš, J. \& Ventura, S. (2013): Description of the cyanobacterial genus Desmonostoc gen. nov. including D. muscorum comb. nov. as a distinct, phylogenetically coherent taxon 
and Evoutionaryl Microbiology 51: 513-526.

Gugger, M.; Lenoir, S.; Berger, C.; Ledreux, A.; Druart, J.C.; Humbert, J.F.; Guette, C. \& Bernard, C. (2005): First report in a river in France of the benthic cyanobacterium Phormidium favosum producing anatoxin-a associated with dog neurotoxicosis. - Toxicon 45: 919-928.

Marathe, A. (2012): Cyclic electron transfer pathways in Synechococcus sp. PCC 7002 cyanobacteria during photosynthesis at high light intensity [PhD. Thesis]. - 133 pp., University of Wisconsin.

Mareš, J. (2010): Anabaena fuscovaginata (Nostocales), a new cyanobacterial species from periphyton of the freshwater alkaline marsh of Everglades, South Florida, USA. - Fottea 10: 235-243.

Miller, M.A.; Pfeiffer, W. \& Schwartz, T. (2012): The CIPRES science gateway: enabling high impact science for phylogenetics researchers with limited resources. - In: Proceedings of the 1st Conference of the Extreme Science and Engineering Discovery Environment: Bridging from the eXtreme to the campus and beyond. - pp. 1-8, ACM, Chicago, Illinois. http://doi.acm.org/10.1145/2335755.2335836

Miller, S.R. \& CASTEnHolz, R.W. (1998): Effects of visible light and UV radiation on photosynthesis in a population of a hot spring cyanobacterium, a Synechococcus sp., subjected to high-temperature stress. - Applied Environmental Microbiology 64: 3893-3899.

Muller, F. (2000): The nature and mechanism of superoxide production by the electron transport chain: its relevance to aging. Journal of the American Aging Association 23: 227-253.

Oren, A. (2000): Salts and brines. - In: Whitton, B. A. \& Pоттs, M. (eds): The ecology of cyanobacteria. Their diversity in time and space. Kluwer Academic Publishers: 281-319. Dordrecht, The Netherlands.

Osorio-Santos, K.; Pietrasiak, N.; Bohunická, M.; MisCOE, L.H.; KovÁČIK, L.; Martin, M.P. \& Johansen, J.R. (2014): Seven new species of Oculatella (Pseudanabaenales, Cyanobacteria). - European Journal of Phycology 49: 450-470.

Paerl, H.W.; Tucker, J. \& Bland, P.T. (1983): Carotenoid enhancement and its role in maintaining blue green (Microcystis aeruginosa) surface blooms.- Oceanography 28: 847-857.

R Core Team (2014): R: A Language and Environment for Statistical Computing. R Foundation for Statistical Computing, Vienna, Austria. ISBN 3-900051-07-0.

Rajaniemi, P.; Hrouzek, P.; Kaštovská, K.; Willame, R.; Rantala, A.; Hoffmann, L.; KomÁrek, J. \& SivoNEN, K. (2005a): Phylogenetic and morphological evaluation of the genera Anabaena, Aphanizomenon, Trichormus and Nostoc (Nostocales, Cyanobacteria). - International Journal of Systematic and Evolutionary Microbiology 55:11-26.

Rajaniemi, P.; Komárek, J.; Willame, R.; Hrouzek, P.; Kaštovská, K.; Hoffmann, L. \& Sivonen, K. (2005b): Taxonomic consequences from the combined molecular and phenotype evaluation of selected Anabaena and Aphanizomenon strains. - Archiv für Hydrobiologie - Algological Studied 117: 371-391.

Rapala, J. \& Sivonen, K. (1998): Assessment of environmental conditions that favour hepatotoxic and neurotoxic Anabaena spp. strains cultured under light limitation at different temperatures. - Microbial Ecology
36: 181-192.

ŘehákovÁ, K.; Mareš, J.; LuKeŠovÁ, A.; ZapomĚlovÁ, E.; BernardovÁ, K. \& Hrouzek, P. (2014): Nodularia (Cyanobacteria, Nostocaceae): a phylogenetically uniform genus with variable phenotypes. - Phytotaxa 172: 235-246.

Ronquist, F.; Teslenko, M.; van der Mark, P.; Ayres, D.L.; Darling, A.; Höhna, S.; Larget, B.; Liu, L.; Suchard, M.A. \& Huelsenbeck, J.P. (2012): MRBAYES 3.2: Efficient Bayesian phylogenetic inference and model selection across a large model space. - Systematic Biology 61: 539-542. Published online 2012 February 22. doi: 10.1093/sysbio/sys029

Schopf, J.W. (1996): Cyanobacteria. Pioneers of the early Earth. - In: Prasad, A.K.S.K.; Nienow, J.A. \& RaO, V.N.R. (eds): Contributions in Phycology. - pp. 1332. Nova Hedwigia, Beiheft 112, Cramer, J., Berlin.

SKÁcelovÁ, O. \& ZAPOMĚLovÁ, E. (2010): Remarks on the occurrence and ecology of several interesting cyanobacterial morphospecies found in South Moravian wetlands. - Acta Musei Moraviae, Scientiae biologicae 95: 201-221.

STAL, L.J. (2000): Cyanobacterial mats and stromatolites. In: Whitton, B.A. \& M. Ротts (eds): The Ecology of Cyanobacteria. - pp. 61-120, Kluwer, Dordrecht.

Stamatakis, A. (2014): "RAxML Version 8: A tool for Phylogenetic Analysis and Post-Analysis of Large Phylogenies". - Bioinformatics. open access link: http://bioinformatics.oxfordjournals.org/content/early/2014/01/21/bioinformatics.btu033.abstract?keytype $=$ ref\&ijkey $=$ VTEqgUJYCDcf0kP

Stulp, B.K. \& Stam, W.T. (1985): Taxonomy of the genus Anabaena (Cyanophyceae) based on morphological and genotypic criteria. - Archiv für Hydrobiologie Suppl. 71: 257-268.

Taton, A.; Grubisic, S.; Brambilla, E.; De Wit, R. \& Wilmotte, A. (2003): Cyanobacterial diversity in natural and artificial microbial mats of Lake Fryxell (McMurdo dry valleys, Antarctica): A morphological and molecular approach. - Applied Environmental Microbiology 69: 5157-5169.

VAn Liere, L. \& Mur, L. R. (1979): Chapter 9. Some experiments on the competition between a green alga and a cyanobacterium $[\mathrm{PhD}$ Thesis]. - $97 \mathrm{pp}$., University of Amsterdam

VAN Liere, L. \& Mur, L.R. (1980). Occurrence of Oscillatoria agardhii and some related species, a survey. Developments in Hydrobiology 2: 67-77.

Wacklin, P.; Hoffmann, L. \& KomÁReK, J. (2009): Nomenclatural validation of the genetically revised cyanobacterial genus Dolichospermum (Ralfs ex Bornet et Flahault) comb. Nova. - Fottea 9:59-64.

Ward, D.M. \& CAstenholz, R.W. (2000): Cyanobacteria in geothermal habitats. - In: Potтs, M. \& Witton, B. A. (eds): Ecology of cyanobacteria: their diversity in time and space. - pp. 37-59, 669, Kluwer Academic Publishers, Dordrecht.

Willame, R.; Boutte, C.; Grubisic, S.; Wilmotte, A.; KomareK, J. \& Hoffmann, L. (2006): Morphological and molecular characterization of planktonic cyanobacteria from Belgium and Luxembourg. - Journal of Phycology 42: 1312-1332.

Wilmotte A.; Van der Auwera, G. \& De Wachter, R. (1993): Structure of the 16S ribosomal RNA of the thermophilic cyanobacterium Chlorogloeopsis HTF 
related to the genus Nostoc. - Fottea 13: 201-213.

Iteman, I.; Rippka, R.; Marsac, N.T. \& Herdman, M. (2002): rDNA analyses of planktonic heterocystous cyanobacteria, including members of genera Anabaenopsis and Cyanospira. - Microbiology 148: 481-496.

Johansen, J.R. \& CAsamatta, D.A. (2005): Recognizing cyanobacterial diversity through adoption of a new species paradigm. - Archiv für Hydrobiologie-Algological Studies. Suppl. 117: 71-93.

Katoh, K. \& Standley, D. M. (2013): MAFFT Multiple Sequence Alignment Software Version 7: Improvements in Performance and Usability. - Molecular Biology and Evolution 30: 772-80.

KomÁReK, J. \& ZAPOMĚLovÁ, E. (2007): Planktic morphospecies of the cyanobacterial genus Anabaena = subg. Dolichospermum - 1. part: coiled types. - Fottea 7: $1-31$.

KomÁReK, J. \& ZapomělovÁ, E. (2008): Planktic morphospecies of the cyanobacterial genus Anabaena $=$ subg. Dolichospermum - 2. part: straight types. - Fottea 8: 1-14.

KomÁReK, J. (2005): Studies on the cyanophytes (Cyanobacteria, cyanoprokaryota) of Cuba 11. Freshwater Anabaena species. - Preslia 77: 211-234.

KomÁrek, J. (2008): The cyanobacterial genus Macrospermum. - Fottea 8: 79-86.

KomÁReK, J. (2010): Recent changes (2008) in cyanobacterial taxonomy based on a combination of molecular background with phenotype and ecological consequences (genus and species concept). - Hydrobiologia 639: 245-259.

KomÁrek, J. (2013): Cyanoprokaryota -3. Teil/ 3rd Part: Heterocytous genera. -In: Büdel, B.; GÄrtner, G.; Krienitz, L. \& Schagerl, M. (eds.): Süsswasserflora von Mitteleuropa. - 1130 pp. Elsevier/Spektrum, Heidelberg.

KomÁrek, J.; Hübel, M.; Hübel, H. \& ŠMarda, J. (1993): The Nodularia studies. 2. Taxonomy. -Algological Studies 68: 1-25.

Komárek, J.; Kaštovský, J.; Mareš, J. \& Johansen, J.R. (2014): Taxonomic classification of cyanoprokaryotes (cyanobacterial genera) 2014 according to the polyphasic approach. - Preslia 86: 295-335.

Kozhevnikov, I.V. \& Kozhevnikova, N.A. (2011): Phylogenetic and morphological evaluation of Wollea saccata (Nostocales, Cyanobacteria) isolated from the Yenissei River basin (Eastern Siberia, Russia). - Fottea 11:99-106.

Kvíderová, J. \& LukavskÝ, J. (2001): A new unit for crossed gradients of temperature and light. - Beiheift Nova Hedwigia 123: 541-550.

LaAmanen, M.J.; Gugger, M.F.; LehtimäKi, J.M.; HauKKA, K. \& Sivonen K. (2001): Diversity of toxic and nontoxic Nodularia isolates (Cyanobacteria) and filaments from the Baltic Sea. - Applied and Environmental Microbiology 67: 4638-4647.

Lorenzen, C.J. (1967): Determination of chlorophyll and phaeo-pigments: Spectrophotometric equation. Limnology and Oceanography 12: 343-346.

Lyra, C.; Suomalainen, S.; Gugger, M.; Vezie, C.; Sundman, P.; Paulin, L. \& Sivonen, K. (2001): Molecular characterization of planktic cyanobacteria of Anabaena, Aphanizomenon, Microcystis and Planktothrix genera. - International Journal of Systematic
('Mastigocladus laminosus HTF') strain PCC7518, and phylogenetic analysis. - FEBS Microbiology Letters 317: 96-100.

Zapomělová, E.; Jezberová, J.; HrouzeK, P.; Hisem, D.; ŘehÁková, K. \& Komárková, J. (2009): Polyphasic characterization of three strains of Anabaena reniformis and Aphanizomenon aphanizomenoides (cyanobacteria) and their re-classification to Sphaerospermum gen. nov. (incl. Anabaena kisseleviana). - Journal of Phycology 45: 1363-1373.

Zapomělová, E.; Hisem, D.; Řeháková, K.; Hrouzek, P.; Jezberová, J.; Komárková, J.; Korelusová, J. \& ZNACHOR, P. (2008a): Experimental comparison of phenotypical plasticity and growth demands of two strains from the Anabaena circinalis / A. crassa complex (cyanobacteria). - Journal of Plankton Research 30: $1257-1270$.

Zapomělová, E.; HrouzeK, P.; ŘehákovÁ, K.; ŠAbacká, M.; Stibal, M.; Caisová, L.; Komárková, J. \& LUKEŠOvÁ, A. (2008b): Morphological variability in selected heterocystous cyanobacterial strains as a response to varied temperature, light intensity and medium composition. - Folia Microbiologica 53: 333-341.

Zapomělová, E.; Hrouzek, P.; Řezanka, T.; Jezberová, J.; ŘehÁKovÁ, K.; Hisem, D. \& KomÁrková, J. (2011): Polyphasic characterization of Dolichospermum spp. and Sphaerospermopsis spp. (Nostocales, Cyanobacteria): morphology, 16S rRNA gene sequences and fatty acid and secondary metabolite profiles. - Journal of Phycology 47: 1152-1163.

Zapomělová, E.; ŘehÁKovÁ, K.; Znachor P.; \& KomÁRKOVÁ, J. (2007): Morphological diversity of coiled planktonic types of the genus Anabaena (cyanobacteria) in natural populations - taxonomic consequences. - Cryptogamie/Algologie 28: 353-371.

Zapomělová, E.; Skácelová, O.; Pumann, P.; Kopp, R.; JANEČEK, E. (2012): Biogeographically interesting planktonic Nostocales (Cyanobacteria) in the Czech Republic and their polyphasic evaluation resulting in taxonomic revisions of Anabaena bergii Ostenfeld 1908 (Chrysosporum gen. nov.) and A. tenericaulis Nygaard 1949 (Dolichospermum tenericaule comb. nova). - Hydrobiologia 698: 353-365.

Supplementary material

the following supplementary material is available for this article:

Table S1.Summary of GenBank sequences used in this study.

This material is available as part of the online article (http://fottea.czechphycology.cz/contents)

(C) Czech Phycological Society (2015)

Received February 12, 2015

Accepted May 18, 2015 